\title{
Correction
}

\section{Correction: Peak plasma interleukin-6 and other peripheral markers of inflammation in the first week of ischaemic stroke correlate with brain infarct volume, stroke severity and long-term outcome}

\author{
Craig J Smith*1,2, Hedley CA Emsley1,2, Carole M Gavin³, \\ Rachel F Georgiou ${ }^{2}$, Andy Vail ${ }^{4}$, Elisa M Barberan², Gregory J del Zoppo ${ }^{5}$, \\ John M Hallenbeck ${ }^{6}$, Nancy J Rothwell 7 , Stephen J Hopkins ${ }^{8}$ and \\ Pippa J Tyrrell 1,2
}

\begin{abstract}
Address: ${ }^{1}$ University of Manchester, Manchester M13 9PT, UK, ${ }^{2}$ Stroke Services, Clinical Sciences Building, Hope Hospital, Salford, M6 8HD, UK, ${ }^{3}$ Accident and Emergency Medicine, Hope Hospital, Salford M6 8HD, UK, 4 Biostatistics Group, University of Manchester, Hope Hospital, Salford M6 8HD, UK, ${ }^{5}$ Department of Molecular and Experimental Medicine, The Scripps Research Institute, La Jolla, CA, USA, ${ }^{6}$ Stroke Branch, National Institute of Neurological Disorders and Stroke, NIH, Bethesda, MD, USA, ${ }^{7}$ School of Biological Sciences, University of Manchester, Manchester M13 9PT, UK and ${ }^{8}$ North Western Injury Research Collaboration (NWIRC), Clinical Sciences Building, Hope Hospital, Salford M6 8HD, UK

Email: Craig J Smith* - csmith@fs1.ho.man.ac.uk; Hedley CA Emsley - hemsley@fs1.ho.man.ac.uk;

Carole M Gavin - Carole.Gavin@srht.nhs.uk; Rachel F Georgiou - rdrennan@fs1.ho.man.ac.uk; Andy Vail - avail@fs1.ho.man.ac.uk; Elisa M Barberan - elisa.barberan@man.ac.uk; Gregory J del Zoppo - grgdlzop@scripps.edu; John M Hallenbeck - hallenbj@ninds.nih.gov; Nancy J Rothwell - Nancy.Rothwell@man.ac.uk; Stephen J Hopkins - shopkins@fs1.ho.man.ac.uk; Pippa J Tyrrell - ptyrrell@fs1.ho.man.ac.uk * Corresponding author
\end{abstract}

Published: 15 March 2004

BMC Neurology 2004, 4:5
Received: 04 March 2004

Accepted: 15 March 2004

This article is available from: http://www.biomedcentral.com/l47/-2377/4/5

(C) 2004 Smith et al; licensee BioMed Central Ltd. This is an Open Access article: verbatim copying and redistribution of this article are permitted in all media for any purpose, provided this notice is preserved along with the article's original URL.

In table 3, the correlation coefficient between peak plasma cortisol and mRS at 3 months (column 4, row 5), should read 0.48 , not 0 [1].

\section{References}

I. Smith CJ, Emsley HC, Gavin CM, Georgiou RF, Vail A, Barberan EM, del Zoppo GJ, Hallenbeck JM, Rothwell NJ, Hopkins SJ, Tyrrell PJ: Peak plasma interleukin-6 and other peripheral markers of inflammation in the first week of ischaemic stroke correlate with brain infarct volume, stroke severity and long-term outcome. BMC Neurol 4(I):2. 2004 Jan 15

\section{Pre-publication history}

The pre-publication history for this paper can be accessed here:

http://www.biomedcentral.com/1471-2377/4/5/prepub
Publish with Biomed Central and every scientist can read your work free of charge

"BioMed Central will be the most significant development for disseminating the results of biomedical research in our lifetime."

Sir Paul Nurse, Cancer Research UK

Your research papers will be:

- available free of charge to the entire biomedical community

- peer reviewed and published immediately upon acceptance

- cited in PubMed and archived on PubMed Central

- yours - you keep the copyright
BioMedcentral 